\title{
Pidana Dalam Hukum Islam Dan Perbandingan Dengan Hukum Pidana Nasional
}

\author{
Teguh Prasetyo
}

Abstrak

The traditional criminal which originates from Islamic Figh has a great philosophical basic to be the source of the national criminal law reform in Indonesia. However, it is relevant to seeks the religious values to establish the new Criminal Law.

\section{Pendahuluan}

Al-Qur'an adalah sumber syariat Islam. al-qur'an pada hakikatnya menempati posisi sentral dalam studi-studi ke-Islaman. Di samping berfungsi sebagai petunjuk (huda), ia menjadi tolok ukur dan pembeda antara kebenaran dan kebatilan, termasuk dalam penerimaan dan penolakan setiap berita yang disandarkan kepada Nabi Muhammad SAW.'

Berhirara kandungan hukum yang dikandung al-Qur'an, maka di dalamnya terkandung hukum (syari'at) yang berhubungan dengan hukum ibadat, hukum keluarga, warisan, hukum tentang harta benda (kekayaan) dan tukar menukar, hukum pidana ('uqubat atau jinayat) dan hukum yang berkaitan dengan problema perdata dan pidana.

Sejauh mana al-Qur'an mengungkapkan tasyi'nya yang berhubungan dengan masalah pidana pada umumnya. Tulisan ini mencoba menjawab: Siapakah orang yang dianggap berbuat tindakan pidana? Tindakan dalam bentuk apakah yang digolongkan dalam tindakan pidana? Bentuk sanksi ('uqubat) apa sajakah yang dijatuhkan sebagai sanksi hukum bagi si pelaku kriminil itu? Siapakah orang yang berkompeten melaksanakan sanksi pidana itu? Apakah yang dimaksud dengan pidana qishash itu? Bagaimana kedudukan pidana qishash itu. Dan bagaimana pula pelaksanaan pidana qishash itu, siapa yang berkompeten melakukan pidana qishash itu? Apakah bedanya pidana dalam Islam dan Pidana dalam hukum nasional?

Metode yang digunakan dalam pembahasan tulisan ini adalah metode tematik (maudluiy).

'M. Quraisy Syhab, Membumikan al-Quran (Bandung: Mizan, 1992), hlm 150. Lihat Yusuf al-Qardlawy, Al-Khashaish al-'Ammah li al-Islam, cet Il, (Beirut: Muassasah al-Risalah, 1983 M/1404 H), hlm 35-38. "*Rubu' artinya seperempat; seperempat (dalam pengertian sebagian) membicarakan tentang masalah jinayat (pidana). Istilah jinayat paling dikenal di kalangan salaf. 


\section{Konsep Pidana Dalam Hukum Islam}

Secara kebahasaan kata-kata "pidana", "uqubat" atau "jarimah", sebagai yang lazim digunakan kalangan fukaha hampir tergambar secara tersurat (manthuq) dalam al-Qur'an, akan tetapi pemahaman tentang pidana akan dapat dipahami secara tersirat (mafhum) dari banyak ayat-ayat yang membicarakan tentang 'uqubat, jinayat atau jarimah ini. Istilah yang paling dikenal untuk pengertian pidana ini di kalangan ulama salaf adalah "al-Jinayat". la dijadikan satu rubu' dalam kitab fiqh mereka. Sedang dikalangan ulama kalaf, mereka menamakan kitab bagian pidana dengan kitab "Al-Uqubat".

Pidana adalah segala bentuk perbuatan yang dilakukan oleh seorang mukallar, yang melanggar perintah atau larangan Allah yang dikhitbahkan kepada orang-orang mukallaf, yang dikarenakan ancaman hukuman, baik sanksi (hukuman) itu harus dilaksanakan sendiri, ditaksanakan penguasa, maupun Allah, baik tempat pelaksanaan hukuman itu di dunia maupun di akhirat.

Di sini dapat dipahami, bahwa setiap tindakan pidana (delik, jarimah) itu harus ada sanksi hukum ('uqubat) yang dikenakan kepada si pelakunya (al-Jany), baik berupa azab neraka, gishash, diyat, had, kafarat maupun fidyah, dimana pelaksana sanksi itu Allah sendiri, penguasa atau pribadi itu sendiri, baik tempat pelaksanaannya itu di dunia maupun di akhirat.
Menurut hukum Pidana Umum, yang dimaksud dengan "tindakan pidana" adalah suatu tindakan (berbuat atau tidak berbuat) yang bertentangan dengan hukum nasional jadi yang bersifat tanpa hak - yang menimbulkan akibat yang oleh hukum dilarang dengan ancaman hukuman. ${ }^{2}$ Jadi unsur yang penting sekali untuk peristiwa pidana (dipandang dari sudut objektif) adalah sifat tanpa hak (onrecht matigheid), yakni sifat melanggar hukum. Di tempat mana tak terdapat unsur tanpa hak, maka tidak ada peristiwa pidana.

Keberadaan ayat-ayat al-Qur'an tentang jarimah, 'uqubat atau jinayat untuk berusaha dengan segala kekuatan yang ada untuk membersihkan masyarakat dari sebab-sebab kriminalitas dan mendidik setiap individu agar beristiqamah dalam hidup dan kehidupan. Namun demikian, hal ini tidak cukup hanya dorongan moral, meskipun dorongan moral itu dijaga dengan sebaik-baiknya. Juga tidak cukup hanya dengan tarbiyah, meskipun tarbiyah itu kebutuhan yang bersifat religi dan syar'i.

Bertitik tolak dari prinsip bahwa hak menetapkan legislasi adalah hak Tuhan, maka fungsi manusia sesungguhnya adalah pelaksana hukum yang telah ditetapkan Tuhan. Manusia tidaklah berhak merekayasa sendiri hukum untuk diterapkan dalam kehidupan mereka, kecuali dalam batas-batas yang diperbolehkan, sebab hal ini merupakan pelanggaran besar terhadap hak otoritas Tuhan Yang Maha Mengetahui sebagai legislator. ${ }^{3}$

\footnotetext{
2 L.J. Van Apeldoom, Pengantar IImu Hukum, terj. Inlejding Tot de Studie van Het Nederlandsche Recht oleh Sadino Urid, cet. XXV, (Jakarta: PT. Pradnya Paramita, 1993), hlm 326. Qishash adalah persamaan dalam tindak balas, seperti bunuh dengan bunuh, memotong telinga dibalas dengan memotong telinga, dan tidak ada qishash jika pembunuhan terjadi antara seorang muslim dengan seorang kafir.(Ibnu al-Araby, Ahkam al-Qur'an, Bagian Kedua, (Beirut: Dar al-Kutub al-Ilmiyah), cet. I, 1988 M/1404 H, hlm 129.

${ }^{3}$ Daud Rasyid, Islam Dalam Berbagai Dimensi (Jakarta: Gema Insani Press, 1998), hlm 186.
} 
Dari hasil penelitian sementara, tidak kurang dari 35 ayat al-Qur'an memiliki indikasi dalam memproyeksikan pengertian pidana. Ayat-ayat itu tersebar di surat-surat al-Baqarah 3 ayat, an-Nisa 5 ayat, al-An'am 1 ayat, al-Maidah 5 ayat, at-Taubah 9 ayat, an-Nahl 1 ayat, al-lsra 3 ayat, asy-Syu'ara 2 ayat, al-Hujarat 1 ayat, Yunus 2 ayat dan asy-Syura 2 ayat.

\section{Kegunaan Pidana Dalam Al-Qur'an}

Jika dilihat dari keberadaan aturan hukum pidana dalam al-Qur'an, maka secara universal dapat dinyatakan kegunaannya untuk :

1. Memelihara agama;

2. Memelihara kehormatan manusia;

3. Melindungi akal;

4. Memelihara harta manusia;

5. Memelihara jiwa manusia; dan

6. Memelihara ketentraman umum.

\section{Uqubat Sebagai Sanksi Agama dan Sanksi Kekuasaan}

Syari'at Islam secara umum melarang melakukan kejahatan dengan ancaman hukuman di akhirat, yang dapat menimbulkan kegentaran hati orang yang beriman untuk berbuat dosa dan tindak kejahatan. Sejalan dengan itu 'uqubat dapat pula menyingkirkan diri dari kejahatan. Kemudian menetapkan pula hubungan duniawi untuk kejahatankejahatan tertentu, di samping adanya azab akhirat. Dengan demikian, sanksi agama dengan sanksi kekuasaan (dunia) dapat bahu membahu dalam menyingkirkan kejahatan dan mencegah manusia mengerjakannya. ${ }^{4}$
Kejatahan-kejahatan yang tersembunyi, yang tidak mungkin dikontrol dan dibuktikan kenyataannya dengan pasti, seperti bergunjing (gibhah), mengumpat, dengki (hasad), benci, dendam, dusta dan lain-lain yang lebih erat hubungannya dengan susila, tetapi kejahatan itu tidak mengambil bentuk positif, seperti perampokan harta, maka untuk kejahatan yang serupa itu cukup dengan ancaman di akhirat, berdasarkan kepercayaan kepada Allah yang mengetahui isi hati setiap hamba-Nya.

Kejahatan yang ada hubungannya dengan pergaulan dan kepentingan umum dan mengakibatkan pengaruh buruk terhadap hak-hak perseorangan dan masyarakat serta telah begitu meluas dan mendalam dampaknya, syari'at Islam menetapkan untuk kejahatan yang demikian itu hukuman duniawi, sedangkan pelaksanaan-nya diserahkan kepada penguasa atau kepada hakim atau mereka yang memiliki kekuasaan yudikatif.

Tindakan kriminal yang menyangkut darah, harta dan kehormatan merupakan bahaya besar, karena itu Allah menetapkan hukum tentang itu, dan hukum yang menyangkut kriminal itu dapat dicabut atau dibatalkan dengan itthad seseorang, karena manusia mengganti dengan hukuman yang lebih enteng, dengan dalih belas kasihan. ${ }^{5}$

\section{Bentuk-bentuk Tindakan Pidana}

Yang dianggap sebagai tindakan pidana dilukiskan al-Qur'an terdapat dalam bentukbentuk :

1. Pembunuhan: menghilangkan jiwa, menghilangkan anggota badan, melukai, pengguguran janin (abortus) dan lain-lain

${ }^{4}$ Mahmud Syaltut, Al-Islam 'Aqidatun wa Syari'atun, cet. III, (Cairo: Dar al-Qalam, 1996), hlm 287.

${ }^{5}$ Muhammad al-Ghazali, Nahwa Tafsir al-Maudluily Suwar al-Qur'an al-Karim, cet. I (Kairo: Dar alSyurug), $1995 \mathrm{M} / 1416 \mathrm{H}$, hlm 78. 
(al-Baqarah : 178);

2. Pencurian (sirqah): termasuk ke dalamnya mengambil milik umum (korupsi), makan harta orang lain tanpa hak, makan harta anak yatim, makan niba dan lain-lain (al-Maidah ; 38-39);

3. Perzinahan: termasuk kedalamnya homoseksual (liwath), lesbian (sihaq), mendatangi binatang dan lain-lain (An-Nur : 3-4);

4. Tuduhan Perzinahan: tuduhan perzinahan bagi muslimah yang baik-baik dan tuduhan berzina terhadap isteri (li'an). (AnNur :4-5);

5. Perusuhan dan pengacauan keamanan: merampok, menodong, menggarong dan lain-lain;

6. Pemberontakan: permusuhan sesama muslim dan memusuhi pemerintah;

7. Kemurtadan: meninggalkan Islam sebagai agama yang telah dipeluknya;

8. Minum khamar: minum zat cair yang memabukkan, menggunakan zat lainnya yang dapat merusak akal dan kesehatan (Al-Maidah : 90-91);

9. Keengganan melaksanakan hukum Allah (Al-Maidah : 44,45 dan 47);

10. Pelanggaran terhadap aturan Allah, yang menyebabkan seseorang harus membayar kafarah ataupun fidyah, termasuk ke dalamnya melanggar sumpah, pelanggaran dalam inram haji atau umroh, terkepung pada musim haji, menzhihar isteri dan lain-lain (Al-Maidah : 89. 95-96).

Dalam kajian ini diarahkan pada upaya pemahaman bentuk-bentuk tradisional mengenai pidana Islam sebagaimana ditentukan dalam al-Quran dan al-Sunnah serta dinamika penatsiran inovatif yang dilakukan oleh para ahli hukum, gagasan dasar yang dikandung oleh konsep pidana Islam, serta berbagai kemungkinan inovasi atau pengembangan bentuk-bentuk pidana Islam itu. Dari segi ini, studi yang dilakukan dalam tulisan ini, dapat disimpulkan ada beberapa bentuk, antara lain :

Secara tradisional, bentuk-bentuk pidana Islam itu meliputi :

a. Pidana qishash atas jiwa;

b. Pidana qishash atas badan;

c. Pidana Diyat (denda ganti rugi);

d. Pidana mati;

e. Pidana penyaliban (salib);

f. Pidana pelemparan batu sampai mati (rajam);

g. Pidana potong tangan atau kaki;

h. Pidana potong tangan dan kaki;

i. Pidana pengusiran atau pembuangan;

j. Pidana penjara seumur hidup;

k. Pidana cambuk atau dera;

l. Pidan denda pengganti diyat (hukuman);

m. Pidana teguran atau peringatan;

n. Pidana penamparan atau pemukulan;

o. Pidana kewajiban religius yang disebut kaffarah;

p. Pidana tambahan lainnya (ta'zier);

q. Bentuk-bentuk pidana lainnya yang dapat dikembangkan sebagai konsekuensi dari pidana ta'zier,

Ketujuh belas bentuk pidana itu, dapat dikelompokkan (diklasifikasikan) sebagai berikut :

a. Dari Segi objek ancamannya

1) Pidana atas Jiwa, yang terdiri dari :

a) Pidana mati dengan pedang;

b) Pidana mati dengan digantung di tiang salib (disalib);

c) Pidana mati dengan dilempar batu (dirajam).

2) Pidana atas harta kekayaan, yang meliputi :

a) Pidana diyat ganti rugi ; 
b) Pidana ta'zier sebagai tambahan;

3) Pidana atas anggota badan, berupa :

a) Pidana potong tangan dan kaki;

b) Pidana potong tangan atau kaki;

c) Pidana penemparan atau pemukulan merupakan variasi bentuk pidana sebagai peringatan dan pengajaran.

4) Pidana atas kemerdekaan, berupa :

a) Pidana pengusiran atau pembuangan;

b) Pidana penjara seumur hidup;

c) Pidana penahanan yang bersifat sementara;

5) Pidana atas rasa kehormatan dan keimanan, berupa :

a) Pidana teguran atau peringatan;

b) Kaffarah sebagai hukuman yang bersifat religius.

\section{Pelaku-pelaku Jarimah dan Sanksi Hukum yang dijatuhkan}

Manakala kita sudah memahami, tindakan-tindakan apa saja yang termasuk ke dalam perbuatan kriminal, maka dengan mudah kita akan dapat memahami, siapa-siapa saja orangnya yang disebut dengan "al-Jany" (yang melakukan tindakan pidana). Mereka adalah :

1. Pembunuhan: al-Qatil, al-Jarih dan asSaqith (an-Nisa':96).

2. Pencuri: as-Sariq dan as-Sariqat (alMaidah: 38).

3. Penzina: az-Zanydan az-Zaniyat (an-Nur. 2).

4. Penuduh zina: al-Qadzif (an-Nur: 4-9).

5. Pengacau dan perusuh: al-Maharib dan al-Fasid (al-Maidah: 33).
6. Pemberontak: al-Bughat (al-Hujurat :9; anNahl: 90; Yunus: 23-27).

7. Orang murtad: al-Murtad (al-Baqarah :217).

8. Peminum arak: syarib al-khamr (al-Maidah :90).

9. Orang Islam atau penguasa yang enggan melaksanakan hukum Allah (al-Maidah: 44-45).

10. Pelanggar terhadap hukum Allah yang mengharuskan membayar kafarah atau fidyah yaitu pelanggar sumpah, penzhihar isteri, al-La'in, pelanggar dalam ibadah haji, atau 'umrah dan terkepung pada musim haji (al-Baqarah: 196).

Pada umumnya setiap tindakan pidana yang dilakukan pelaku pidana mendapatkan sanksi hukum ('uqubat)nya. Bentuk-bentuk 'uqubat itu sesuai dengan berat ringannya perbuatan (tindak) pidana yang dikerjakan.

Di kalangan fukaha ada yang berpendapat bahwa dikenal tiga macam tindak pidana, bila ditinjau dari segi hukumnya, yaitu jarimah hudud, jarimah qishash atau diyat dan jarimah ta'zir. ${ }^{6}$ Namun ada juga yang menggolongkan empat macam yaitu 'uqabat itu dalam bentuk:

1. Al-Hudud, sanksi hukum yang tertentu dan mutlak yang menjadi hak Allah, yang tidak dapat dirubah oleh siapapun. Sanksi itu wajib dilaksanakan, manakala syaratsyarat dari tindak pidana itu terpenuhi. Sanksi ini dikenakan kepada kejahatankejahatan berat seperti zina, sariqah, riddah, qadzaf dan lain-lain;

2. Al-Qishash dan al-Diyat. Al-Qishash adalah sanksi hukuman pembalasan seimbang, seperti membunuh terhadap si pembunuh. Al-Diyat adalah sanksi hukuman dalam

${ }^{6}$ Juhaya S Praja, Figh Jinayah Hukum Pidana Islam, Pengantar Seminar Kullah Program Pasca Sarjana Ilmu Hukum Bidang Studi Hukum Pidana (Bandung: Universitas Islam Bandung, 2000), hlm 1. 
bentuk ganti rugi, seperti jika ahli waris si terbunuh memberi maaf maka hukuman alternatif adalah diyat.

Sanksi hukum al-Qishashdan al-Diyatadalah merupakan sanksi hukum perpaduan antara hak Allah dan hak manusia.

3. Al-Ta'zir, adalah sanksi hukum yang diserahkan kepada keputusan hakim atau pihak berwenang yang berkompeten melaksanakan hukuman itu, seperti memenjarakan, mengasingkan dan lainlain. ${ }^{7}$

4. Kafarat dan fidyah, adalah sanksi hukum dalam bentuk membayar denda, yang diserahkan pelaksanaannya kepada si pelanggar. Bentuk denda ini dapat berupa memerdekakan budak, berpuasa, penyembelihan atau memberi makan orang miskin.

\section{Pelaksanaan Sanksi Tindak Pidana}

Siapakah yang berkompeten melaksanakan sanksi-sanksi dari tindakan pidana itu? Dari keterangan Al-Qur'an, yang berwenang melaksanakan sanksi-sanksi hukuman itu adalah :

1. Allah, umumnya berlaku untuk sanksi hukuman di akhirat berupa azab neraka (lihat al-Baqarah: 217; at-Taubah: 68 dan an-Nisa' :93).

2. Hakim (penguasa), lazimnya dilaksanakan untuk sanksi hudud dan qishash (lihat anNur: 2; al-Maidah : 33, 38 dan 45).

3. Pribadi yang bersangkutan, umumnya untuk sanksi denda dalam kafarah dan fidyah (lihat al-Baqarah: 196 dan al-Maidah : 45).

\section{Prosedur dan Tehnik Pelaksanaan serta Pelaksana Tindak Pidana}

Di bawah ini akan diutarakan sanksisanksi hukum yang akan diberikan oleh pelaksana sanksi pidana terhadap pidana yang dilaksanakan.

\section{Pembunuhan}

Dalam pembunuhan yang sengaja (anNisa' : 193), maka sanksinya dikenakan qishash yaitu pembalasan yang setimpal (al-Baqarah : 178). Orang merdeka balasannya adalah orang merdeka. Jika keluarga pembunuh memaafkan dari qishash, maka sanksinya beralih kepada diyat berat, yang diserahkan kepada keluarga si terbunuh. Sanksi serupa ini dijatuhkan juga bagi pembunuhan juga bagi pembunuhan "serupa sengaja". Bagi "pembunuhan tersalah", maka sanksinya diyat ringan. ${ }^{8}$ (an-Nisa' :92).

Dalam kasus terakhir ini, si pembunuh malah dikenakan dua sanksi, pertama; kafarah, dengan memerdekakan seorang budak wanita beriman dan kedua; harus membayar denda ringan.

Demikian juga apabila mendapat serangan bagi yang berhaji di bulan haram, maka harus dibalas setimpal (al-Baqarah: 45).

Pelaksanaan dari qishash dilakukan hakim, setelah semua persyaratan benar benar terpenuhi untuk itu.

Pembunuhan janin karena takut miskin

${ }^{7}$ Lihat Ibnu Rusyd, Op.Cit, hlm 394-459, perhatikan Daud Rasyid, Islam dalam Berbagai Dimensi (Jakarta: Gema Insani Press, 1998), hlm 192-193.

${ }^{8}$ Ibnu Rusyd, Bidayat al-Mijtahid wa Nihayat al-Muqtashid, juz II, cet. III (Singapura: Sulaiman Mar'iy, t.t), him 409. 
adalah merupakan tindakan pidana yang besar, di mana sanksinya akan diberikan Allah (al-Isra': 33 dan al-An'am:151).

Pembunuhan terhadap jiwa tanpa hak, seperti pembantaian terhadap kelompok tertentu, pembunuhan terhadap tawanan perang, wanita dan anak - anak dalam peperangan dan pembunuhan di saat sudah ada perjanjian genjatan senjata adalah perbuatan pidana (al-An'am : 151).

Pembunuhan-pembunuhan besar terakhir ini tidak disebutkan secara tegas, akan tetapi dapat dipahami bahwa tindakan ini mengandung dosa dan akan ada sanksi di sisi Allah.

\section{Pencurian}

Pencurian adalah mengambil barangbarang kepunyaan orang lain (tanpa hak) secara sembunyi dan secara sengaja untuk maksud memiliki. ${ }^{9}$

Pencuri yang melakukan pencurian, yang memenuhi persyaratan yang ditentukan, akan dikenakan sanksi hukuman had dalam bentuk potong tangan, yang dilaksanakan oleh penguasa (al-Maidah: 38-39).

Pencurian harta umum/negara secara diam-diam dalam bentuk korupsi atau kolusi dapat dimasukkan ke dalam pencurian. Demikian juga memanfaatkan atau mengambil harta orang lain tanpa hak (al-Baqarah : 168 dan an-Nisa' : 29), termasuk juga dalam pencurian, memakan harta anak yatim (diluar haknya). Sanksinya adalah neraka (an-Nisa': 10). Makan riba adalah pula suatu tindakan kriminal yang akan mendapat sanksi dari Allah (al-Baqarah : 275-276). Jual beli yang mengurangi takaran adalah tindakan kriminal, yang akan mendapatkan sanksi dari Allah (al-Isra' : 35 dan asy-Syu'ara : 181-182).

\section{Perzinahan}

Perzinahan adalah hubungan kelamin yang terjadi antara seorang pria dengan seorang wanita yang tidak diikat oleh hubungan perkawinan yang sah. Ini adalah suatu perbuatan pidana yang diancam dengan sanksi had dengan cambuk (jilid) 100 kali untuk masing-masing pihak. Pelaksana sanksi adalah penguasa (hakim) atau orang yang berwenang untuk itu (an-Nur : 2).

\section{Tuduhan perzinahan}

Tuduhan perzinahan itu ada dua bentuknya, pertama; menuduh muslimah yang baik-baik berbuat zina dan kedua; menuduh isterinya sendiri berbuat zina.

Tuduhan perzinahan pertama, apabila tidak dapat mendatangkan empat orang saksi, yang mampu membenarkan perzinahan yang dituduhkan, maka kepada si penuduh dikenakan sanksi had, dengan cara penguasa mencambuknya delapan puluh kali. Penguasa melaksanakan hak itu kepada si penuduh walaupun tidak diminta oleh tertuduh ${ }^{10}$ (an-Nur :41).

Tuduhan perzinahan bentuk kedua adalah "il'an", dimana seorang suami menuduh isterinya berbuat zina, yang dikuatkan dengan sumpah empat kali dan pada kali kelima ia mengatakan : "bahwa laknat Allah kepadanya jika ia berbuat dusta". Pada saat itu, isterinya dapat dikenakan had zina, karena ia (seolah-olah) sudah

\footnotetext{
${ }^{8}$ Lihat Ibnu Rusyd, op cit., him 106

10 Muhammad Ali as-Sayis, Tafsir Ayat al-Ahkam Muqarrar li al-Sanat ats-Tsalitsat, Muhammad Abi Shabih wa Auladuhu (Mesir: Kairo, 1953 M/1373 H), hlm 126.
} 
berzina. Untuk membebaskan diri dari had zina, si isteripun melakukan pembelaan dengan mengucapkan sumpahempat kali yang menyatakan kedustaan suaminya dan pada kali yang kelima ia menyebutkan : "bahwa Allah marah kepadanya, jika ia (suami) termasuk orang yang benar". "Dengan demikian si isteripun terlepas dari had zina, sebagaimana suami terlepas dari had zina karena li'an."11 (an-Nur :6-9).

\section{Pengacauan dan perusuhan}

Bagi yang melakukan kekacauan dan kerusuhan, dipilah-pilah kepada beberapa bentuk tindak pidana, maka berbeda-beda pula sanksi hukumnya. Bagi si pembunuh sanksinya hukuman bunuh (qishash). Jika ia membunuh dan mengambil hartanya maka sanksinya hukuman salib. Jika mengambil harta saja, sanksi hukumannya dipotong kaki dan tangan secara berlawanan. Jika ia mengganggu di jalanan (ikhafah al-sabil), maka sanksinya dibuang. ${ }^{12}$ Pelaksanaan sanksi dilakukan penguasa (al-Maidah : 33-34).

\section{Pemberontakan}

Jika ada kelompok yang memberontak atau memusuhi sesama muslim, maka disuruh perangi, sehingga takluk dan berdamailah dan berbuat adil. Perbuatan permusuhan itu dilarang Allah dan dimasukkan ke dalam al-baghyu (lihat al-Hujurat : 9 dan an-Nahl : 90).

\section{Kemurtadan}

Riddah adalah keluar dari agama Islam.
Maka baginya diberi kesempatan untuk bertobat. Jika ia tidak mau bertobat, maka sanksi hukumnya adalah dibunuh, mereka tidak dipotong kaki dan tangan dan tidak dibuang ${ }^{13}$ (al-Baqarah: 217).

\section{Minum khamar}

Minum khamar adalah suatu tindakan pidana. Peminumnya berbuat dosa. Al-Qur'an tidak menegaskan sanksi hukumnya. Sanksi hukumnya dijelaskan hadits berupa had, yang dijelaskan penguasa (al-Maidah : 90-91).

\section{Keengganan melaksanakan hukum Allah}

Keengganan melaksanakan aturan hukum yang telah ditetapkan Allah adalah merupakan suatu perbuatan pidana, karena sifat ketidakpatuhan pada diri makhluk-Nya, sehingga Allah menetapkan mereka sebagai orang yang kufur, orang yang dialim dan orang yang fasiq. Mereka pada hakekatnya disiksa karena kekufurannya (al-Maidah: 44), disiksa karena kedialimannya (al-Maidah : 45) dan disiksa karena kefasiqkannya (al-Maidah : 47).

\section{Pelanggaran terhadap aturan-aturan ibadat dan mu'amalat yang mengharuskan si pelanggar membayar kafarah ataupun fidyah.}

Bagi yang melanggar sumpah, maka sanksinya berupa kafarah dengan memberi makan sepuluh orang miskin, atau memberi pakaian atau memerdekakan budak atau berpuasa tiga hari. Pelaksanaannya dilakukan

\footnotetext{
"Ibid., h.141.

${ }^{12}$ Ibnu al-'Araby, op.cit., hlm 106

${ }^{13}$ lbid., hlm .93.
} 
sendiri oleh si pelanggar (al-Maidah : 89).

Bagi mereka yang terkepung, maka ia harus membayar fidyahnya dengan menyembelih dam dan bagi mereka yang sakit atau ada gangguan di kepala, maka sanksinya dengan berfidyah yaitu berpuasa atau bersedeqah atau berkorban. Apabila melakukan haji tamattu', maka wajib memberikan fidyah dengan menyembelih dam atau berpuasa tiga hari di tanah haram dan tujuh hari manakala sudah berada di kampung halaman (al-Baqarah : 196).

\section{Perbandingan Pidana Islam dengan Hukum Nasional}

Mengenai gagasan dasar yang dikandung oleh sistem pidana dan pemidanaan dalam tradisi Islam dan Pidana Nasional, antara lain, pengkajian yang dilakukan dalam tulisan ini menemukan hal-hal sebagai berikut :

1. Sistem Hukum Islam, tidak membedakan secara tegas antara konsep hukum perdata dan hukum pidana sedangkan dalam Hukum nasional dibedakan secara jelas. Hal ini terutama terlihat dalam konsep hukum Islam mengenai sanksi qishash dan diyat yang memberikan kepada pihak korban hak untuk menuntut penjatuhan pidana kepada pelaku;

2. Dalam sistem pidana Islam, kepentingan korban sangat diperhatikan dan karena itu ancaman yang diberikan kepada setiap pelaku kejahatan bersifat sangat tegas dalam hukum nasional sanksi hukumannya tidak begitu berat. Jaminan ketertiban hukum dan keadilan dalam masyarakat ditata sedemikian rupa sehingga setiap perbuatan jahat yang dianggap menganggu ketertiban dan tatanan keadilan itu diancam secara tegas oleh sistem sanksi yang keras dan terhadap korban dari perbuatan jahat itu diberikan sedemikian rupa sehingga kepentingannya sangat diperhatikan.

3. Secara historis, penentuan bentuk dan berat ringannya pidana dalam al-Quran maupun al-Sunnah, mencerminkan kebijaksanaan legislatif yang maju dan berkembang serta semakin memperhatikan prinsip-prinsip asasi akan rasa keadilan dan kemanusiaan dalam masyarakat sedangkan dalam hukum nasional kurang mencerminkan kebijaksanaan karena tidak dikenal unsur pemaaf. Hal itu terlihat dalam kenyataan bahwa bentuk-bentuk dan kadar ancaman pidana dalam tradisi Islam itu, sedemikian apabila dibandingkan dengan tradisi pidana sebelum Islam. ${ }^{14}$ Sebagian dari bentuk-bentuk dan kadar ancaman pidana Islam itu merupakan penyederhanaan dan penghalusan terhadap tradisi hukum pidana Yahudi dan Nasrani maupun praktik masyarakat Arab Jahiliyah. Dalam tradisi hukum Islam, prinsip yang bersifat meringankan beban itu disebut dengan prinsip adam al-kharaj (peniadaan kesulitan). Prinsip ini berkaitan dengan prinsip al-tadrij fi al-tasyri' (pembebanan secara berangsur-angsur), dan prinsip taqiil al-takalif (pembebanan sedikit demi sedikit);

Oleh karena itu, setiap usaha yang bersifat legislatif dalam rangka merumuskan

${ }^{14}$ Pada umumnya, tradisi pidana sebelum Islam bersifat sangat keras dan berorientasi kepada pembalasan terhadap setiap tingkah laku yang dianggap menyimpang dari keharusan umum. Bahkan untuk sebagian, dapat dikatakan bahwa tradisi hukum pidana sebelum Islam lebih mencerminkan kepentingan elite daripada banyak. Lihat, dalam Jimly Ash-Shiddiqie, Pembaharuan Hukum Pidana Indonesia (Bandung: Angkasa, 1995), hlm. 53. 
bentuk-bentuk pidana dari sumber hukum pidana Islam, terutama di zaman modern sekarang ini, haruslah juga mempertimbangkan prinsip - prinsip yang bersifat semakin meringankan beban subjek hukum.

Dalam rangka memenuhi tuntutan perkembangan kebutuhan masyarakat modem dewasa ini, bentuk-bentuk tradisional pidana Islam itu sendiri yang merupakan produk dari usaha memahami petunjuk Tuhan dalam al-Qur'an dan teladan yang dipraktikkan Nabi melalui hadist-hadisnya, perlu dikembangkan lebih lanjut sesuai dengan kebutuhan menurut ruang dan waktu. Artinya untuk kebutuhan-kebutuhan bersifat lokal dan aktual dalam masyarakat Indonesia dewasa ini, bentuk-bentuk pidana Islam itu sendiri dapat dikembangkan lebih lanjut dengan melihat gagasan dasar yang dikandungnya dan dengan mempertimbanghkan sifat-sifat kebutuhan masyarakat Indonesia secara nasional. Peluang religius untuk pengembangan itu, pada dasarnya sangat terbuka, terutama karena adanya prinsip inovasi yang dikembangkan dalam konsep ta'zier. Dengan adanya pidana ta'zier itu maka : Bentuk-bentuk pidana yang ditetapkan maupun soal berat ringannya pidana itu, sejauh mengenai ancaman pidana terhadap bentuk-bentuk kejahatan yang belum diterangkan di dalam al-Qur'an dan al-Hadis, dapat dikembangkan dengan melihat kepada efektifitas pidana itu senditri dalam rangka mencapai tujuan yang diharapkan sistem hukum Islam. Karena itu, bentuk pidana apa pun yang diancam terhadap jenis-jenis kejahatan demikian, sepanjang tidak bertentangan dengan gagasan dasar sistem pidana Islam, dapat diterima sebagai bagian dari gagasan Islam itu sendiri.

Tradisi penerapan pidana Islam dalam konteks kebijaksanaan yudikatif, memberikan wewenang yang luas kepada hakim untuk menentukan berbagai kemungkinan pengembangan bentuk-bentuk pidana Islam itu. Atas prakarsa hakim, bentuk-bentuk pidana Islam itu dapat dikembangkan sedemikian rupa untuk memenuhi tuntutan kebutuhan masyarakat, baik mengenai kadar berat ringannya maupun pidananya itu sendiri.

Ada relevansi secara asasi dalam bidang asas-asas antara hukum pidana Islam dengan yang selama ini dianut dalam $\mathrm{KUHP}^{15}$ antara lain :

1. Asas Legalitas

Yang dimaksud dengan asas legalitas adalah asas yang menyatakan bahwa tidak ada pelanggaran dan tidak ada hukuman sebelum ada undang-undang yang mengaturnya. Asas ini didasarkan pada al-Qur'an (QS. $17: 15$ ), dihubungan dengan anak kalimat dalam (QS. $6: 19$ ), yang berbunyi ..."Al-Qur'an ini diwahyukan kepadaku, agar (dengannya) aku dapat menyampaikan peringatan (dalam bentuk aturan dan ancaman hukuman) kepadamu ...". Asas legalitas ini telah ada dalam hukum Islam sejak al-Qur'an diturunkan.

2. Asas Larangan Memindahkan Kesalahan pada Orang lain

Asas ini terdapat didalam berbagai surat

${ }^{15}$ Mohammad Daud Ali, Hukum Islam, Pengantar IImu Hukum dan Tata Hukum Islam di Indonesia, (cet.V) (Jakarta: PT Raja Grafindo Persada, 1996), him.117. 
dan ayat Al-Qur'an (QS. 6 :164), (QS. 35 : 18), (QS. 39: 7), (QS. $53: 38$ ), (QS. 74 : 38) misalnya dinyatakan bahwa setiap jiwa terikat pada apa yang dia kerjakan, dan setiap orang tidak memikul dosa atau kesalahan yang diperbuat oleh orang lain (QS. 74 : 38). Di bagian (QS. 6 : 164) Allah Menyatakan bahwa setiap pribadi yang melakukan sesuatu kejahatan akan menerima balasan kejahatan yang dilakukannya. Ini berarti bahwa tidak boleh sekali-kali beban (dosa) seseorang dijadikan beban (dosa) orang lain. hal itu karena tanggung jawab pidana itu individual sifatnya, kesalahan seseorang tidak dapat dipindahkan kepada orang lain.

3. Asas Praduga Tak bersalah

Dari ayat-ayat yang menjadi sumber asas legalitas dan asas tidak boleh memindahkan kesalahan kepada orang lain tersebut diatas, dapat ditarik juga asas praduga tidak bersalah. Seseorang yang dituduh melakukan sesuatu kejahatan harus dianggap tidak bersalah sebelum hakim dengan bukti-bukti yang meyakinkan menyatakan dengan tegas kesalahannya itu.

4. Lingkungan Berlakunya Aturan Pidana Secara teoritis, ajaran Islam itu untuk seluruh dunia. Akan tetapi, secara praktis sesuai dengan kenyataan-kenyataan yang ada, tidak demikian.

Para ulama dahulu membagi dunia ini menjadi tiga klasifikasi: ${ }^{16}$

a. Negara-negara Islam;

b. Negara-negara yang berperang dengan Negara Islam; dan

c. Negara-negara yang mengadakan perjanjian damai dengan Negaranegara Islam. Arah dan semangat ajaran Islam bukan kepada perang, melainkan kepada damai.

Para ulama Islam terdapat tiga macam pendapat tentang masalah ini, yaitu: teori dari Imam Abu Hanifah; teori dari Imam Abu Yusu; dan teori dari Imam Malik, Iman Syafi'i, dan Imam Ahmad.

Imam Abu Hanifah menyatakan bahwa aturan pidana itu hanya berlaku secara penuh untuk wilayah-wilayah negeri muslim. Di luar negeri muslim, aturan tadi tidak berlaku lagi, kecuali kejahatankejahatan yang berkaitan dengan hak perseorangan (haqq al-adamiy). Teori ini mirip dengan teori teritorialitas.

Imam Abu Yusuf berpendapat bahwa sekalipun di luar wilayah Negara muslim, aturan itu tidak berlaku. Akan tetapi, setiap yang dilarang tetap haram dilakukan, sekalipun tidak dapat dijatuhi hukuman. Teori ini mirip dengan teori nasionalitas. Sedangkan Imam Malik, Imam Syafi'i, dan Imam Ahmad berpendapat bahwa aturanaturan pidana itu tidak terikat oleh wilayah, melainkan terikat oleh suyek hukum. Jadi, setiap muslim tidak boleh melakukan halhal yang dilarang dan atau meninggalkan hal-hal yang diwajibkan. Teori ini mirip dengan teori internasionalitas.

\section{Perspektif Masuknya Unsur Pidana Islam dalam Hukum Pidana Nasional}

Ada beberapa relevansi yang begitu sinergik antara hukum pidana Islam dengan

${ }^{16}$ A. Djazuli, Figh Jinayah (Upaya Menanggulangi Kejahatan dalam Islam) (Jakarta: Raja Grafindo Persada, 1997), him 9. 
sistem kehidupan masyarakat Indonesia, sehingga hal itu merupakan nilai tambah (edit value) bagi kontribusi hukum pidana Islam dalam rangka pembentukan KUHP Modern di Indonesia, baik menurut tinjauan teori pemidanaan modern, tinjauan sosiologis maupun tinjauan yuridis dan filosofis.

Secara filosofis, tradisi pidana dari sumber figh Islam yang akrab di kalangan mayoritas pendudukan Indonesia, mempunyai landasan filosofis yang kuat untuk dijadikan sumber bagi usaha pembaharuan hukum pidana nasional. Sila Ketuhanan Yang Maha Esa dalam Pancasila yang merupakan sila pertama, utama dan menyinari serta mengayomi keempat sila-sila lainnya, sangat memungkinkan dikembangkan sistem hukum yang religius. Karena itu sumber-sumber yang bersifat religius, seperti hukum Pidan Islam, sangat relevan untuk digali dalam rangka pembentukan KUHP baru. Demikian pula secara yuridis konstitusional, tidak ada larangan untuk menjadikan tradisi pidana Islam itu sebagai sumber pembentukan KUHP Nasional. Bahkan dalam konstitusi Republik Indonesia, yaitu UUD 1945, keberadaan agama dan Ketuhanan Yang Maha Esa djunjung tinggi dalam hukum dan peradilan di Indonesia

\section{Simpulan}

Dari beberapa uraian di atas, maka kita dapat menarik beberapa kesimpulan sebagai berikut :

1. Dalam al-Qur'an ditemukan banyak ayat yang berkaitan dengan masalah pidana.

2. Tujuan dari diturunkannya ayat pidana itu antara lain, untuk memelihara agama, kehormatan diri manusia, melindungi akal, melindungi harta manusia, memelihara jiwa dan ketenteraman umum.
3. Surat-surat yang terdapat di dalamnya ayat pidana adalah pada surat-surat alBaqarah 3 ayat, an-Nisa' 5 ayat, al-An'am 1 ayat, al-Maidah 5 ayat, at-Taubah 9 ayat, an-Nahl 1 ayat, al-Isra' 3 ayat, asy-Syu'ara 2 ayat, al-Hujurat 1 ayat, Yunus 2 ayat dan asy-Syura 2 ayat.

4. Tindakan-tindakan pidana yang dikenakan sanksi pidana adalah pembunuhan, pencurian, perzinaan, tuduhan perzinahan, perusuhan dan pengacauan, pemberontakan, kemurtadan, minum khamar, keengganan melaksanakan hukum Allah dan pelanggaran terhadap aturan Allah yang mengharuskan membayar kafarat dan fidyah.

5. Bentuk-bentuk sanksi hukum pidana adalah al-hudud, al-qishash, al-ta'zir, kafarat dan fidyah.

6. Orang yang berwenang melaksanakan sanksi pidana adalah Allah, hakim (penguasa) dan pribadi yang bersangkutan.

7. Qishash adalah suatu hukuman yang lebih bersifat keadilan dan persamaan, bukan balas dendam.

8. Sistem pidana dan pemidanaan dalam tradisi Islam dan Pidana Positif di Indonesia, mengenai Sistem Hukum, ancaman yang diberikan kepada setiap pelaku kejahatan bersifat sangat tegas dalam hukum nasional sanksi hukumannya tidak begitu berat, dalam Pidana Islam memperhatikan prinsip-prinsip asasi akan rasa keadilan dan kemanusiaan dalam masyarakat sedangkan dalam hukum nasional kurang mencerminkan kebijak-sanaan karena tidak dikenal unsur pemaaf. 


\section{Daftar Pustaka}

al-Araby, Ibnu, Ahkam al-Qur'an, Bagian Kedua, Beirut: Dar al-Kutub al-limiyah, cet. I, $1988 \mathrm{M} / 1404 \mathrm{H}$.

al-Ghazali, Muhammad, Nahwa Tatsir alMaudlu'iy Suwar al-Qur'an al-Karim, cet. I, Kairo: Dar al-Syurug, 1995 M/ $1416 \mathrm{H}$.

al-Qardlawy, Yusuf, Al-Khashaish al-'Ammah Ii al-Islam, cet II, Beirut: Muassasah alRisalah, $1983 \mathrm{M} / 1404 \mathrm{H}$.

Apeldoom, L.J. Van, Pengantar Ilmu Hukum, tej. Inlejding Tot de Studie van Het Nederlandsche Rechtoleh Sadino Urid, cet. XXV, Jakarta: PT. Pradnya Paramita, 1993.

as-Sayis, Muhammad Ali, Tafsir Ayat al-Ahkam Muqarrar li al-Sanat ats-Tsalitsat, Muhammad Abi Shabih wa Auladuhu, Mesir: Kairo, 1953 M/1373 H.

Daud Ali, Mohammad, Hukum Islam, Pengantar IImu Hukum dan Tata Hukum Islam di Indonesia, (cet.V), Jakarta: PT Raja
Grafindo Persada, 1996.

Djazuli, A., Figh Jinayah (Upaya Menanggulangi Kejahatan dalam (slam), Jakarta: Raja Grafindo Persada, 1997.

Praja, Juhaya S, Figh Jinayah Hukum Pidana Islam, Pengantar Seminar Kuliah Program Pasca Sarjana IImu Hukum Bidang Studi Hukum Pidana, Bandung: Universitas Islam Bandung, 2000.

Rasyid, Daud, Islam Dalam Berbagai Dimensi, Jakarta: Gema Insani Press, 1998.

Rusyd, Ibnu, Bidayat al-Mijtahid wa Nihayat alMuqtashid, juz II, cet. III, Singapura: Sulaiman Mar'iy, t.t.

Shiddiqie, Jimly Ash-, Pembaharuan Hukum Pidana Indonesia, Bandung: Angkasa, 1995.

Syaltut, Mahmud, Al-Islam 'Aqidatun wa Syari'atun, cet. III, Cairo: Dar al-Qalam, 1996.

Syhab, M. Quraisy, Membumikan al-Quran, Bandung: Mizan, 1992. 